\title{
GELIAT, DILEMA SATU RUMAH DUA NEGARA DAN TRADISI KEAGAMAAN SEBAGAI KEKUATAN PEMERSATU DI KALANGAN MUSLIM SEBATIK
}

\section{WRIGGLING, ONE HOUSE TWO COUNTRIES DILEMMA AND RELIGIOUS TRADITIONS AS A UNIFYING FORCE AMONG SEBATIK MUSLIMS}

\author{
Abd. Kadir Ahmad \\ Balai Litbang Agama Makassar \\ Email: ahmadkadir56@gmail.com
}

Naskah diterima tanggal 5 Maret 2020, Naskah direvisi tanggal 2 Mei 2020, Naskah disetujui tanggal 9 Juni 2020

\begin{abstract}
Abstrak
Peningkatan kualitas kehidupan masyarakat di daerah perbatasan menjadi perhatian pemerintah dalam satu kesatuan semangat membangun Indonesia dari pinggir untuk mencapai keutuhan bangsa dan peningkatan kemaslahatan masyarakat. Salah satu prasyarat kemaslahatan masyarakat adalah terjaganya persatuan, khususnya umat Islam. Penelitian ini bertujuan mengkaji dan mendalami tradisi keagamaan sebagai modal kultural dan sosial masyarakat Sebatik untuk meningkatkan persatuan dalam masyarakat. Penelitian menggunakan pendekatan kualitatif dengan wawancara mendalam, pengamatan, dan kajian dokumen digunakan untuk mengumpulkan data. Analisis penelitian dilakukan secara deskriptif dan analitik melalui mekanisme dan proses reduksi data, display data dan verifikasi data. Dokumen dianalisis dengan menggunakan analisis isi. Temuan penelitian menunjukkan (1) sejumlah isu sosial, ekonomi, dan keamanan, sebagai konsekuensi dari posisi Sebatik sebagai daerah perbatasan; (2) meski demikian, masalah-masalah yang muncul tidak menggoyahkan persatuan dan kesatuan masyarakat setempat dan kawasan perbatasan antar kedua negara; (3) salah satu faktor pengikat persatuan tersebut adalah modal sosial dan budaya berupa tradisi keagamaan sebagai inti budaya dari masyarakat yang didukung oleh budaya dominan orang Bugis.
\end{abstract}

Kata Kunci: persatuan, tradisi keagamaan, sebatik, masyarakat perbatasan

\begin{abstract}
Improving the quality of life of the people in the border areas is the concern of the government in a united spirit to develop Indonesia from the edge to achieve national integrity and increase community benefit. One of the prerequisites for the benefit of the community is the maintenance of unity, especially Muslims. This study aims to examine and explore religious traditions as cultural and social capital of the Sebatik people to increase unity in society. The study used a qualitative approach with in-depth interviews, observations, and document reviews used to collect data. The research analysis was conducted descriptively and analytically through the mechanism and process of data reduction, data display and data verification. Documents were analyzed using content analysis. Research findings indicate (1) a number of social, economic, and security issues, as a consequence of Sebatik's position as a border area; (2) however, the problems that arose did not shake the unity and integrity of the local community and the border region between the two countries; (3) one of the binding factors of unity is social and cultural capital in the form of religious traditions as the cultural core of the society supported by the dominant culture of the Bugis people.
\end{abstract}

Keywords: unity, religious tradition, sebatik, border society

\section{PENDAHULUAN}

$\mathrm{P}$ erat uran Presiden RI No. 2 Tahun 2015 tentang Rencana Pembangunan Jangka Menengah Nasional (RPJMN) 2015-
2019, memuat daerah perbatasan sebagai salah satu prioritas pembangunan nasional. Hal itu tertuang dalam Nawacita, yaitu membangun Indonesia dari pinggiran dengan 
memperkuat daerah-daerah dan desa dalam kerangka negara kesatuan. Salah satu daerah perbatasan Indonesia dengan Malaysia adalah Pulau Sebatik, Kabupaten Nunukan Provinsi Kalimantan Utara. Perbatasan antara kedua negara ditandai dengan 22 buah patok beton sebagai bat as negara. Batas seperti ini dikenal sebagai artificial boundaries (tanda batas buatan manusia) untuk dibedakan dengan natural boundaries (perbatasan yang terbentuk karena proses alamiah) (John Bernando Seran dalam Bangun, 2017).

Perbatasan Wilayah Indonesia dan Malaysia di Pulau Sebatik ditentukan berdasarkan kesepakatan Inggris dan Belanda tahun 1891 melalui Konvensi London dan tahun 1915 lewat Protokol London. Wilayah bagian Utara masuk dalam wilayah kekuasaan Inggris dan wilayah bagian Selatan merupakan bagian dari kekuasaan Belanda (Saleh, 2015). Sejak abad ke-17, kongsi dagang Hindia Belanda (VOC) sudah mulai memperluas wilayah koloni mereka ke Borneo Timur atau Kalimantan Utara. Tahun1672, di suatu kawasan pantai yang disebut Tanjung Tinagat (kini Tawau), Belanda membuka perkampungan baru. Inggris, di lain pihak, telah menguasai India, Burma, semenanjung Malaya, dan Singapura, hingga ke Sarawak, Berunei dan Sabah. Bahkan Belanda berhasil dihalau keluar dari Tawau dan menyingkir ke Kampung Pembeliangan (kini berada di Kabupaten Nunukan) (Batubara, 2016).

Belanda dan Inggris mengikuti tradisi penentuan perbatasan yang telah dijadikan sistem bernegara di Eropa sejak abad ke-16. Perjanjian Westphalia umumnya dianggap perjanjian internasional pertama yang menetapkan prinsip kedaulatan negara (Diener \& Hagen, 2010). Pada abad ke-18 dan 19, perbatasan memasuki era di mana masyarakat menerapkan kekuasaan dan membangun seperangkat instrumen untuk mengonsolidasikan wilayah. Prosedur ditetapkan untuk mengidentifikasi, memformalkan dan menyelesaikan masalah perbatasan. Perbatasan dalam era globalisasi sekarang ini dipandang titik singgung kekuatan keamanan global, perdagangan arus migrasi, teknologi, penentuan nasib sendiri dan regionalisasi di seluruh dunia (Konrad, 2013).

Diskusi dalam literatur menunjukkan enam prinsip pengorganisasian utama mengenai perbatasan. Pertama, penentuan nasib sendiri bagi suatu bangsa yang mengakibatkan terjadinya pemisahan diri dan munculnya perbatasan baru mengikuti ketentuan yang dibuat oleh Perjanjian Westphalia (1648) dan ditegaskan kembali untuk dunia modern dalam Perjanjian Paris (1919). Penentuan nasib sendiri dan kedaulatan telah menjadi prinsip pengorganisasian global sejak pembentukan Perserikatan Bangsa - Bangsa pada tahun 1945, di mana negara-negara penanda tangan mencapai hampir 200 negara.

Kedua, perbatasan dihasilkan oleh kebijakan dan isu-isu tata kelola yang kompleks. Selama awal abad ke-20, para ahli mencari penjelasan sederhana tentang tujuan dan sifat perbatasan. Saat ini, perbatasan dipahami sebagai konstruksi kelembagaan yang timbul dari perjanjian internasional di antara negara-negara yang menyetujui. Ia merupakan sarana untuk menegakkan garis demarkasi. Sejak peristiwa 11 September, sebagian besar pemerintah nasional telah melakukan investasi besar-besaran dalam keamanan perbatasan, terutama di Amerika Utara dan Eropa (Konrad, 2013).

Ketiga, perbatasan tergantung pada budaya masyarakat perbatasan setempat. Meskipun perbatasan internasional membagi negara-negara tanpa kewarganegaraan, masyarakat perbatasan dapat tetap dipersatukan oleh budaya (etnis, bahasa dan / atau agama) atau lembaga politik lokal (Konrad dan Nicol, 2011).

Keempat, perbatasan bergantung pada pengaruh politik masyarakat perbatasan, apakah komunitas lintas batas bekerja sama atau mereka mengalami ketegangan atau ketidaksetaraan. Ada banyak contoh hubungan yang mapan dan banyak juga contoh ketegangan lintas batas lokal. Kota dua negara yang berbatasan dapat mewakili ketegangan atau menjalin keterkaitan atau keduanya. 
Kelima, pasar dan arus migrasi memiliki implikasi signifikan terhadap perbatasan. Urgensi arus orang, barang, informasi dan mata uang di perbatasan perlu dipahami sepenuhnya. Wilayah ekonomi lintas batas muncul dari wilayah perbatasan yang homogen secara budaya. Ruang tempat digantikan oleh ruang aliran dan bahwa dalam kondisi seperti itu "negara bangsa modern telah kehilangan banyak kedaulat annya".

Akhirnya, perbatasan selalu bergerak dalam pengertian bahwa komunitas, negara, negara bagian, dan kekuasaan, serta perbatasan di antara mereka, terus-menerus dalam proses membuat dan tidak membuat. Perbatasan juga dapat ditempa dan dapat beradaptasi dengan konstruksi dan rekonstruksi negara-bangsa ini. Penerimaan terhadap variabilitas historis perbatasan, dikombinasikan dengan kelenturannya, dan perasaan bahwa perbatasan terus-menerus dibayangkan, diperebutkan dan direkonstruksi melalui waktu, membantu kita untuk mulai memahami dan mengekspresikan mutabilitas perbatasan dalam ruang dan waktu (Konrad, 2013).

Hubungan antara Indonesia dan Malaysia yang diwakili oleh Pulau Sebatik memunculkan realitas unik pada daerah tersebut. Isu-isu sebagaimana dibicarakan pada teori perbatasan di atas menempatkannya sebagai tempat interaksi budaya, pertukaran, dan hibriditas, yaitu tempat untuk interaksi antara individu dari berbagai latar belakang. Kenyataan seperti ini menurut Diener dan Hagen adalah bahwa perbatasan merupakan pemisah tetapi juga dilintasi, garis sekaligus transisi, batas dan peluang, dan perbatasan adalah binari. (Diener \& Hagen, 2010) (Konrad, 2013).

Pulau Sebatik menggambarkan realitas seperti disebutkan di atas. Kawasan perbatasan ini berhadapan dengan Distrik Tawau, wilayah Sabah, Malaysia bagian timur yang ibukotanya Kota Kinabalu. Pulau Sebatik berada di antara Nunukan (ibukota Kabupaten Nunukan) dan Kota Tawau. Selat Sebatik yang memisahkan Pulau Nunukan dan Pulau Sebatik jaraknya kurang lebih 3-4 kilometer, sedangkan Sebatik dengan Tawau dipisahkan oleh selat yang lebarnya sekitar 8 mil laut $( \pm 12.8 \mathrm{~km})$.

Posisi Sebatik seperti itu menempatkannya dalam tarikan kepentingan kedua negara pada banyak aspeknya baik sosial, ekonomi, dan keamanan. Namun demikian, relasi kedua daerah bertetangga ini dapat dilihat dalam hubungan yang tidak seimbang. Bidang ekonomi, misalnya, Tawau merupakan bagian dari fenomena ekonomi kota, sementara Sebatik adalah bagian dari ekonomi desa (rural). Secara ekonomi dan pembangunan Tawau lebih mapan dan maju ketimbang Sebaik. Sistem yang lebih mapan akan cenderung mengeksploitasi sistem yang kurang mapan. Posisi yang tidak seimbang seperti itulah yang membuat Sebatik cenderung terserap energinya oleh tetangganya.

Itulah sebabnya mengapa Indonesia menjadikan pembangunan di perbatasan negara sebagai salah satu prioritas pembangunan nasional. Pengembangan kawasan perbatasan negara yang selama ini dianggap sebagai pinggiran negara, diarahkan menjadi halaman depan negara yang berdaulat, berdaya saing, dan aman. Sasaran pembangunan daerah perbatasan dimaksudkan, antara lain, untuk meningkatkan keamanan dan kesejahteraan masyarakat perbatasan.

Keamanan dan kesejahteraan menjadi penting sebagai peluang sekaligus problem daerah perbatasan. Isu-isu tentang terorisme dan lalu lintas transaksi narkoba sering dikaitkan dengan posisi Sebatik sebagai daerah perbatasan. Tentu saja selain masalah ekonomi khususnya praktik ilegal dalam transaksi ekonomi oleh warga di kedua negara. Kementerian Agama sendiri melihat masalah kesejahteraan dan keamanan ini dari aspek Pendidikan Agama, atau lebih luas Pendidikan Keagamaan. Hal inilah yang akan dilihat pada penelitian ini: Penyelenggaraan Pendidikan Keagamaan di daerah tersebut.

Peraturan Pemerintah Nomor 55 Tahun 2007 Tentang Pendidikan Agama dan Pendidikan Keagamaan menyebutkan Pendidikan Keagamaan sebagai bentuk pendidikan yang mempersiapkan peserta didik untuk dapat menjalankan peranan yang 
menuntut penguasaan pengetahuan tentang ajaran agama dan/atau menjadi ahli ilmu agama dan mengamalkan ajaran agamanya. Pendidikan keagamaan diselenggarakan pada jalur pendidikan formal, nonformal, dan informal. Penyelenggara pendidikan keagamaan bukan hanya pemerintah tetapi lebih banyak oleh masyarakat baik secara individual maupun kelembagaan. Dengan demikian, pendidikan keagamaan cakupannya luas, termasuk tradisi keagamaan yang dilestarikan masyarakat dalam bentuk amalan dari generasi ke generasi.

Namun demikian, karena penelitian ini dilakukan oleh tim, saya memfokuskan pada setting historis, sosial, dan budaya, di atas mana pendidikan keagamaan beroperasi. Dengan demikian, gambaran utuh mengenai totalitas pendidikan keagamaan dari berbagai aspeknya dapat tercapai. Penelitian menggunakan pendekatan kualitatif dengan wawancara mendalam, observasi dan kajian dokumen sebagai metode pengumpulan data. Analisis yang digunakan adalah analisis kualitatif deskriptif melalui proses reduksi data, penyajian data dan verifikasi data secara interaktif dan simultan. Data yang diperoleh melalui dokumen dilakukan analisis isi.

\section{PEMBAHASAN}

\section{Geliat Sebatik}

Pulau Sebatik bukan hanya milik Indonesia, tetapi juga sebagiannya adalah milik Malaysia. Sebatik Indonesia sendiri sebelah utara berbatasan dengan perairan Tawau, sebelah timur berbatasan dengan perairan Ambalat, sebelah selatan berbatasan dengan perairan Nunukan, dan sebelah barat berbatasan dengan Sabah (Malaysia). Pada awalnya, Pulau Sebatik hanya sebuah Desa dan merupakan bagian dari Nunukan. Barulah pada tahun 1999 st at usnya meningkat menjadi kecamatan (Kabupaten Nunukan), berdasarkan Peraturan Pemerintah Nomor 38 Tahun 1996. Sepuluh tahun kemudian (berdasarkan Peraturan Daerah Nomor 03 Tahun 2006) pemerintah memekarkannya menjadi dua kecamatan yaitu Kecamatan Sebatik dan Kecamatan Sebatik Barat.

Berselang lima tahun berikutnya dilakukan lagi pemekaran menjadi lima kecamatan, yaitu Kecamatan Sebatik, Kecamatan Sebatik Barat, Kecamatan Sebatik Timur, Kecamatan Sebatik Utara, dan Kecamatan Sebatik Tengah (Ghafur, 2016).

Sebatik, sebagai daerah perbatasan negara, memperoleh perhatian khusus dari aspek pengamanan. Pos-pos pengamanan dalam setiap jarak tertentu mewarnai pinggir jalan sepanjang perjalanan dari pelabuhan di Desa Bambangan dan Desa Binalawan menuju pusat kota di Pulau Sebatik. Isu keamanan perbatasan, narkoba dan teroris dikaitkan dengan ketatnya pengamanan tersebut. Tidak heran kalau pihak otoritas pengaman setempat, khususnya Koramil, memiliki data lengkap luas wilayah dan kependudukan pulau itu. Pihak yang berkepentingan dengan informasi wilayah dan kependudukan merujuk kepada data tersebut. Tahun 2019 ini Koramil mencatat luas wilayah Sebatik adalah 47.142 Ha dengan jumlah penduduk 43.886 jiwa (22.650 laki-laki dan 21.236 perempuan).

Pemanfaatan lahan (land use) umumnya untuk daerah perkebunan (33.508 Ha) dan fungsi hutan/rawa (2.167 Ha). Hanya sebagian kecil untuk fungsi pertanian (629 Ha). Selain itu terdapat fungsi lainnya untuk permukiman $(9.415 \mathrm{Ha})$. Kecenderungan pemanfaatan lahan untuk permukiman ini akan terus mendesak fungsi lainnya sejalan dengan laju pertumbuhan penduduk sekitar 2,5 persen. Angka ini, misalnya dilihat lima tahun terakhir, dengan jumlah penduduk 36.876 tahun 2014 dibanding 41.425 jiwa tahun 2018 (Nunukan dalam Angka 2015 dan 2019). Trend ini jauh di atas laju pert umbuhan penduduk nasional $(1,49 \%)$.

Dinamika pertumbuhan penduduk di Pulau Sebatik selain pertumbuhan alami juga faktor migrasi termasuk limpahan warga Indonesia yang dideportasi dari Malaysia juga banyak yang menetap di Sebatik. Adanya fenomena di at as menunjukkan bahwa Sebatik dan Nunukan bukan lagi sekedar daerah transit tetapi berkembang menjadi daerah tujuan (Siburian, 2012).

Pertumbuhan penduduk berkembang bersamaan dengan pengembangan wilayah dan infrastruktur Pulau Sebatik. Lebih dari setengah abad sebelumnya, Sebatik hanya sebuah kawasan hutan yang masih "perawan". 
Hanya beberapa titik yang dihuni orang Tidung, kelompok etnis pertama yang bermukim di Pulau Sebatik sejak abad 17. Mereka bermukim di tiga buah desa Kecamatan Sebatik Barat (Sani, 2018). Selain penduduk asli Tidung, di bagian timur barulah sekelompok keluarga Bugis mulai merintis permukiman baru. Tahun 1967 Haji Badorahim dan keluarganya berlabuh di tempat yang sekarang disebut Sei Pancang itu. Sebelumnya, di daerah Liang Bunyu, sudah ada Ambo Mang bin Haji Midok diyakini sebagai orang pertama yang membawa keluarganya menetap di Sebatik pada 1940 (Batubara, 2016).

Berbasis rintisan itu, kemudian terbentuklah kampung demi kampung yang dihubungkan jalan-jalan setapak. Sesama orang Bugis pun dari lain tempat berdatangan dan membentuk koloni sendiri. Maka, seperti terlihat sekarang ini, komunitas-komunitas berbasis etnis pun terbentuk, ada kampung dengan dominan warga dari Bone, Soppeng, Wajo, dan daerah-daerah lainnya (Ansar bin Haji Badorahim, Wawancara).

Berkat rintisan itu lama kelamaan terbentuk kampung-kampung kemudian menjadi desa, dan akhirnya ditingkatkan menjadi beberapa kecamat an seperti sekarang. Masyarakat berharap dengan lima kecamatan, salah satu persyaratan untuk peningkatan status Sebatik menjadi Kabupaten sudah terpenuhi. Harapan itulah yang keluar dari semangat kebersamaan orang-orang Sebatik untuk mendukung dan mempersembahkan suara mayoritas terhadap Jokowi pada Pilpres 2019.

Jalan-jalan tanah dan pengerasan yang menghubungkan antara satu ujung ke ujung lain pulau ini disulap menjadi jalan beraspal. Jalan beraspal itu bagaikan ring road dengan dua ujungnya berawal dan berakhir di Desa Binalawan dan Desa Bambangan Kecamatan Sebatik Barat. Kedua desa ini merupakan pelabuhan yang menghubungkan Sebatik dengan Nunukan. Titik simpul kedua jalur ini berada di Sungai Nyamuk, Sebatik Timur. Perbukitan dan jurang yang terjal yang orang di sana sebut bukit menangis - membuat pengendara menangis untuk bisa lewat saat musim hujan - disulap menjadi jalan aspal yang mulus meski masih rawan longsor. Jarak tempuh berjam-jam sebelumnya, sekarang dapat ditempuh kurang dari satu jam. Bagaikan kota kecil di sana terdapat tiga buah hotel, pusat perbelanjaan, kantor perwakilan bank-bank nasional dan sumber daya ekonomi lainnya.

Potensi sumber daya alam dan lingkungan Sebaik, pengembangan wilayah pemerintahan, infrastruktur jalan dan pembangunan fasilitas pemerintahan dan sumber daya ekonomi, membuat Sebatik semakin menarik dan menantang. Komposisi penduduk pun tidak lagi homogen seperti sebelumnya, meski dengan tetap didominasi orang Sulawesi Selatan, yang orang di sana menyebutnya orang Bugis. Menurut catatan Koramil setempat, Berdasarkan keturunan tercatat penduduk Jawa 250 orang $(0,6 \%)$, Sulawesi 41.516 orang $(95 \%)$, penduduk asli/Tidung 877 orang $(2 \%)$, dan penduduk campuran 1.239 orang $(2,8 \%)$. Sumber data lain menyebutkan, orang Bugis mencapai $70 \%$, menyusul etnis Jawa Tidung, Dayak Agaba, Timor, dan Lombok (Batubara, 2016).

Pekerjaan penduduk pun berkembang menurut jenisnya. Namun demikian, pekerjaan di bidang pertanian (termasuk perkebunan) dan perikanan (nelayan) masih dominan. Setidaknya $11,3 \%$ penduduk bergerak di bidang pertanian dan $8 \%$ di perikanan. Sejarah kedatangan orang-orang dari luar Sebatik adalah sejarah tentang pertanian dan perikanan. "Dulu di sini jayajayanya coklat tahun 1987, saya juga bekerja menangkap ikan di laut", kata Haji Takka, seorang perantau dari Soppeng. Penduduk rata-rata menanam coklat. Haji Abdullah pimpinan Tarekat Khalwatiyah di Kampung Baru menyatakan hal yang sama. "Kami di sini berkebun coklat, sejak kami datang sekitar awal tahun 1980-an".

Lama kelamaan era komoditas kelapa sawit menggeser tanaman coklat. Banyak lahan masyarakat yang beralih fungsi menjadi perkebunan kelapa sawit. "Bupati menyiapkan lahan sawit sehingga orang yang bekerja di Malaysia boleh kembali ke sini. Jadi salah satu penarik di sini adalah adanya lahan sawit yang disiapkan Pemda", tutur Ahmad Nur, Kepala KUA di Sebatik, yang mengaku 
"alumni” Tawau. Pengusaha perkebunan sawit pun sudah bermunculan. Peneliti menyaksikan salah seorang pemilik warung dari Wajo kelihatan menerima setoran dari pekerja kebun sawit miliknya dalam uang ringgit. Selain berusaha membuka warung makan ia juga mengaku berinvestasi di perkebunan sawit, yang digarap orang lain. Namun demikian, upah yang relatif lebih tinggi di Malaysia dan masih terbatasnya perkebunan sawit di kawasan itu, membuat masih banyak warga setempat yang mengadu nasib di perkebunan sawit Malaysia.

Perkembangan kecamatan Sebatik menjadi lima kecamatan menjadi salah satu faktor banyak penempatan PNS di Sebatik. Ada sekitar 1,3\% (531 orang) orang-orang yang bekerja sebagai ASN di Sebatik. Mereka terdiri dari ANS, Pamong, TNI dan Polri. Mereka ini lebih besar porsinya dari pekerja di bidang perdagangan dan konstruksi (masingmasing $0,6 \%$ ).

Perkembangan pekerjaan di luar sektor pertanian dimungkinkan oleh semakin meningkatnya tingkat pendidikan masyarakat setempat. Ada $2,3 \%$ orang yang duduk di perguruan tinggi. Sebanyak 12,6 yang duduk di SMA/sederajat dan $13 \%$ duduk di SLTP/sederajat. Jumlah tertinggi adalah mereka yang duduk di sekolah dasar (28\%).

\section{Dilema Satu Rumah Dua Negara}

Oscar J. Martinez membagi daerah perbatasan ke dalam empat tipe. Pertama, alienated borderlands. Model ini merujuk pada daerah perbatasan di mana pertukaran lintas batas rutin sehari-hari praktis tidak ada karena kondisi yang sangat tidak menguntungkan. Peperangan, perselisihan politik, nasionalisme yang kuat, permusuhan ideologis, permusuhan agama, perbedaan budaya, dan persaingan etnis merupakan penyebab utama keterasingan tersebut. Perselisihan internasional mengarah pada militerisasi dan pembentukan kontrol yang kaku terhadap lalu lintas batas.

Kedua, co-existent borderlands. Koeksistensi muncul antara perbatasan berbatasan ketika negara-bangsa mereka masing-masing mengurangi konflik terkait perbatasan internasional yang masih ada ke tingkat yang dapat dikelola atau, dalam kasus di mana kondisi internal yang tidak menguntungkan di satu atau kedua negara menghalangi kerja sama binasional, ketika masalah tersebut diselesaikan pada tingkat yang stabilitas perbatasan minimal dapat menang.

Ketiga, interdependent borderlands. Suatu kondisi saling ketergantungan lahan perbatasan ada ketika suatu wilayah perbatasan dalam satu negara secara simbiotik terkait dengan wilayah perbatasan negara yang berdampingan. Saling ketergantungan seperti ini dimungkinkan oleh hubungan internasional yang relatif stabil dan dengan adanya iklim ekonomi yang menguntungkan yang memungkinkan warga perbatasan di kedua sisi garis untuk merangsang pertumbuhan dan pembangunan yang terkait dengan modal asing, pasar, dan tenaga kerja. Semakin besar aliran sumber daya ekonomi dan manusia melintasi perbatasan, semakin besar kedua ekonomi akan terikat secara struktural satu sama lain. Hasil akhirnya adalah terciptanya sistem ekonomi yang saling mengunt ungkan.

Keempat, integrated borderlands. Pada tahap ini, negara-negara tetangga menghilangkan semua perbedaan politik utama di antara mereka dan hambatan yang ada untuk perdagangan dan pergerakan manusia melintasi batas timbal balik mereka (Gambar 1.4). Penduduk perbatasan bergabung secara ekonomi, dengan modal, produk, dan tenaga kerja mengalir dari satu sisi ke sisi lain tanpa batasan serius. Nasionalisme membuka jalan bagi ideologi internasionalis baru yang menekankan hubungan damai dan peningkatan kualitas hidup orang-orang di kedua negara melalui perdagangan dan difusi teknologi. Masingmasing negara rela melepaskan kedaulatannya ke tingkat yang signifikan demi mencapai kemajuan bersama. (Schofield, 1994).

Teori tentang artificial borderlands, seperti disebutkan sebelumnya, tepat untuk menggambarkan Sebatik sebagai batas Indonesia dan Malaysia. Dapat dibayangkan sebuah wilayah yang membelah dua negara hanya diberikan tanda batas berupa patok beton yang tidak lebih besar dari pohon kelapa 
dan tingginya kurang dari setengah badan manusia. Menurut anggota TNI penjaga perbatasan di Aji Kuning, jumlah patok pembatas tidak lebih dari 22 buah, dengan jarak $2 \mathrm{~km}$ antar patok.

Simbol yang menandakan wilayah Indonesia dikenali dengan adanya bendera merah putih dan rumah-rumah penduduk di sepanjang tapal batas. Wilayah Malaysia di seberang patok tidak satu pun kelihatan bendera atau simbol negara Malaysia lainnya. Termasuk patroli pengamanan tentara Malaysia pun jarang kelihatan. Salah satu sebabnya, karena wilayah Malaysia di Sebatik lebih merupakan tanah perkebunan sawit daripada pemukiman penduduk.

Penduduk yang ada dengan rumahrumahnya di seberang patok perbatasan, adalah warga Sebatik Indonesia sendiri yang membangun rumah di bagian wilayah Sebatik Malaysia. Seorang warga yang ada di garis batas kedua negara mewakafkan rumahnya untuk "dipermak", di mana bagian depan rumah merupakan wilayah Indonesia dan bagian belakangnya masuk dalam wilayah Malaysia. Bagian belakang rumah sedang direhabilitasi saat penelitian ini dilakukan. Menurut rencana, bagian belakang rumah itu akan "dipermak" dengan khas rumah Malaysia.

Simbol satu rumah dua negara itu sebenarnya menggambarkan, secara teoretis, perbatasan Indonesia-Malaysia di Sebatik termasuk dalam kategori integrated borderland. Kecuali bidang politik dan administrasi, keduanya terintegrasi dalam praktik kehidupan sehari-hari, baik dalam kehidupan sosial, ekonomi, dan budaya. Lebih dari yang lainnya, sektor ekonomi mendominasi faktor lainnya. Ekonomi lintas batas muncul dari wilayah perbatasan yang homogen secara budaya. Ruang tempat digantikan oleh ruang aliran dan bahwa dalam kondisi seperti itu negara bangsa modern telah kehilangan banyak kedaulatannya.

Kedaulatan negara terkalahkan oleh tradisi lintas batas memanfaatkan celah-celah ruang dan waktu yang membuat para pelintas batas rutin ke Tawau bebas dari perangkat imigrasi kedua negara. Sesuatu yang sepertinya sulit dihindari karena setengah dari kebutuhan sehari-hari orang Sebatik adalah merupakan produk dari Malaysia. Sebaliknya hasil perkebunan dari pertanian masyarakat setempat dipasarkan ke Tawau, meski pada gilirannya, orang Sebatik juga harus membelinya kembali dari sana. Akibatnya, bukanlah barang aneh jika di Sebatik, makanan tradisional Bugis yang dijual di pagi hari dapat dibeli dengan rupiah atau dengan ringgit. Anak-anak sekolah pun lebih banyak membeli jajanan dengan ringgit.

Soal ringgit ini, peneliti terlibat diskusi dengan dosen Fakultas Ekonomi Universitas Borneo. Ia dipanggil Pak Peter, salah seorang tim peneliti di sekitar Perputaran Rupiah di Pulau Sebatik. Ia menjelaskan dalam rumah tangga orang Sebatik selalu ada ringgit dan rupiah. Hal itu dikaitkan dengan kebutuhan sehari-hari masyarakat setempat yang dominan berasal dari Tawau. Sebelum tahun 1985 bahkan hampir tidak dikenal uang rupiah. Selain karena perubahan status desa menjadi kecamatan, juga karena anak-anak di Sebatik sudah mulai banyak berinteraksi ke luar. Itulah yang membuat transaksi dengan rupiah meningkat. "Jadi di sini kalau mau belanja kita ditanya pakai rupiah atau ringgit, kalau pakai rupiah kita kena cas karena nilai rupiah rendah", katanya. Kedua, mengapa banyak pakai ringgit, karena misalnya sawit dan ikan kan dijualnya di sebelah, pakai ringgit. Umumnya mamin (makan minum) dibeli dari sebelah (Tawau) (Peter, wawancara, 29/6/2019).

Ada beberapa faktor yang membuat fenomena hubungan lintas batas seperti di Sebatik terjadi. Hal yang sama terjadi pada perbatasan Malaysia dengan Thailand, di mana terjadi fenomena lintas batas komunitas muslim Thailand-Malaysia. Pertama, kesamaan dalam bahasa, agama, kepercayaan, adat istiadat, ritual, rakyat dan permainan. Kedua, kekerabatan baik oleh garis keturunan dan pernikahan. Ketiga fitur geografis. Kekuatan ini mendorong warga perbatasan untuk melakukan perdagangan, menyesuaikan, dan menggunakan strategi kelompok atau jaringan untuk bernegosiasi dengan kebijakan pemerintah Thailand dan Malaysia dan pengawas perbatasan. 
Hubungan dalam perdagangan beras lintas batas Melayu-Muslim terdiri dari hubungan vertikal dan horizontal. Hubungan vertikal adalah keterlibatan pribadi dalam sistem kekerabatan sementara hubungan horizontal dibentuk melalui kepercayaan di antara para profesional dalam jaringan (Khan, 2015).

Faktor budaya, hubungan kekerabatan, dan faktor geografis, membuat hubungan Sebatik dengan Tawau dalam berbagai dimensinya menjadi sesuatu yang sulit terelakkan. Keadaan seperti itulah yang disebutkan oleh (Konrad, 2013) bahwa "pasar dan arus migrasi memiliki implikasi signifikan terhadap perbatasan. Arus orang, barang, informasi dan mata uang di perbatasan perlu dipahami sepenuhnya". Itulah yang disebut oleh Camat setempat sebagai tantangan.

Tantangan kita di sini adalah karena wilayah perbatasan. Mestinya harus ada pintunya (perlintasan resmi). Ini tidak ada, ini permasalahannya. Jadi orang banyak nyolong, banyak yang cari-cari kesempatan, baik itu aparat, ya kalau aparat namanya oknum. Ini yang menjadi PR kita di perbatasan ini. Mudah-mudahan pemerintah pusat dengan kewenangannya bisa membuka PLBN (Pos Lintas Batas Negara), sehingga secara resmi pintunya ada. Kita bertetangga dengan Tawau kan, bapak lihat. Arus pelintasan itu sudah demikian ramai, kan begitu (wawancara).

Pak Camat menyebut kondisi ini sebagai hambatan sekaligus sedikit keanehan. Yang berbatasan langsung dengan Tawau ada di Sebatik, sementara pintu (lintas batas) ada di Tarakan dan di Nunukan. Jadi kalau orang Sebatik mau ke sebelah (Tawau), mesti berputar dulu ke Tarakan atau Nunukan. Ia menyebutkan, dulu ada istilah pintu tradisional untuk perlintasan, tetapi sekarang Malaysia sudah tutup. Perahu-perahu kecil pun boleh menyeberang dengan difasilitasi Surat Pelintas Batas. Sekarang Malaysia tidak mau lagi. Alasannya, sering terjadi insiden kecelakaan. Malaysia menginginkan perlintasan resmi, sesuai dengan standar penyeberangan internasional dan sistem transportasi yang safety.
Camat dan orang-orang Sebatik mengakui dan juga kenyataan menunjukkan bahwa soal lintas melintas itu merupakan hal biasa. "Di sini juga sudah biasa, satu keluarga ada yang di sebelah, ada yang di sini. Anaknya juga sekolah di sini. Itu sudah biasalah, sudah tidak diperiksa lagilah, karena yang di sana juga biasanya simpan (punya) KTP, mungkin juga ada IC-nya (KTP Malaysia)", kata Camat menambahkan.

Tidak jarang penduduk Sebatik dan penduduk Malaysia memiliki dua identitas kewarganegaraan. Jadi mereka bebas keluar masuk. Hanya saja dengan ditutupnya jalur perlintasan tradisional, warga yang memiliki hubungan keluarga di Tawau terkendala untuk sering bertemu. Menantu Haji Badorahim mengaku: "Tahun 1960-an orang tua ke Tawau, saya menyusul tahun 1969. Adik saya menjadi warga negara di sana, karena kelahiran di sana. Mama tiri saya memang orang sana. Kalau mau ketemu keluarga harus melalui imigrasi (di Tarakan atau Nunukan), jadi susah" (wawancara).

Bukan hanya perlintasan resmi yang dikeluhkan masyarakat setempat tetapi juga soal administrasi dan dokumen kependudukan. Kepala Desa Aji Kuning mengaku banyak warganya yang migran, bekerja di sebelah. Dokumen kependudukannya tidak jelas. Kalau anakanaknya mau sekolah di sini (Sebatik Indonesia) mereka akan mengalami kendala karena tidak memiliki akte kelahiran dan tidak memiliki Kartu Keluarga (KK). Dampaknya sangat banyak, bukan hanya soal kepentingan untuk pendidikan, tetapi juga pernikahan, pelayanan kesehatan di Puskesmas dan pendataan pemilih untuk pemilihan umum.

Kepala Desa Limau mengaku sudah 40 tahun berada di desanya dan sudah pernah menyaksikan warganya di Company (Perusahaan Sawit) di Sebatik Malaysia. Dia sedih melihat anak-anak Indonesia di sana: "Anak-anak kita tidak difasilitasi baik pendidikan agama, pendidikan umum maupun kesehatan. Kami datang di sana, kita lihat sebagian ada identitas, sebagian tidak". Ia menyebutkan, pihak company lebih suka pekerja yang tidak memiliki dokumen daripada yang punya. Pekerja yang memiliki 
dokumen upahnya stabil, sementara yang tidak punya, diupah sesukanya. Persoalan lain adalah banyak pekerja di bawah umur, termasuk menikah di bawah umur.

Dilema perbatasan di atas terkait dengan ketentuan (pasal 8) bahwa Instansi Pelaksana melaksanakan urusan Administrasi Kependudukan dengan kewajiban yang meliputi: (1) mendaftar Peristiwa Kependudukan dan mencatat Peristiwa Penting; (2) memberikan pelayanan yang sama dan profesional kepada setiap Penduduk atas pelaporan Peristiwa Kependudukan dan Peristiwa Penting (UU Republik Indonesia Nomor 24 Tahun 2013 tentang Perubahan Atas UU Nomor 23 Tahun 2006 tentang Administrasi Kependudukan.

Terkait dengan itu, Kepala Desa setempat mengakui mengurusi warga perbatasan sudah merupakan bagian dari masalah kemanusiaan. Banyak faktor yang tidak boleh dilakukan secara administrasi tetapi harus dilakukan karena faktor teknis. Hal itu sudah menjadi karakteristik perbatasan yang perlu mendapat perhatian. Sebab seperti kata Konrad, perbatasan selalu bergerak dalam pengertian bahwa komunitas, negara, dan kekuasaan, terus-menerus dalam proses membuat dan tidak membuat. Penerimaan terhadap variabilitas historis perbatasan, dikombinasikan dengan kelenturannya, dan perbatasan terus-menerus direkonstruksi melalui ruang dan waktu (Konrad, 2013).

Meski dapat dikategorikan sebagai integrated borderlands, arus orang dan barang antara kedua negara, lewat kawasan setempat, berlangsung secara tidak seimbang. Kecenderungan arus orang Indonesia ke Malaysia lebih tinggi ketimbang sebaliknya, sementara arus barang lebih besar dari Malaysia ke Indonesia ketimbang sebaliknya. Pengalaman menyeberang ke Tawau (4/7) menunjukkan dua hal yang kontras. Pada bagian imigrasi Malaysia para penumpang kapal laut yang menggunakan paspor merah (Malaysia) yang datang dari Indonesia dapat dihitung dengan jari. Sementara pemegang paspor hijau antriannya panjang. Hal itu mudah dimengerti karena sejarah kedua kota. Tawau adalah kota lama yang sudah masuk kategori kota besar dan maju sementara Sebatik dan Nunukan merupakan bagian dari fenomena desa dan Kabupaten yang baru mulai berkembang.

Ketimpangan itulah yang membuat orang Indonesia menyeberang ke Tawau, termasuk menetap di sana.

Haji Tahang bin Basira seorang pemandu kereta pribadi. Ia membawa kami keliling bandar Tawau, melihat tempat-tempat perbelanjaan dan kawasan kebun sawit. Ia berasal dari Lamurukung Bone dan ke Tawau tahun1970. Awal datang di sini, apa saja dilakukan, termasuk bolak balik Sungai Nyamuk menyelundupkan rokok ke Tawau. Dari sini ia bawa bawang dan keperluan sehari hari. Sekitar setahun dia lakukan aktivitas itu. Akhirnya ia berhenti dan menjadi pemandu kereta truk. Lama kelamaan ia beralih ke taksi dan punya mobil sendiri (merek Proton Saga). Ia memiliki tiga orang anak dua laki-laki yang bekerja sebagai police di Kuala Lumpur dan Keke (Kinabalu). Anak perempuannya bekerja sebagai nurse. Anak-anaknya lulusan universitas di Keke. Semangat belajar orang Bugis dinilai sangat tinggi, karena mereka tahan menderita walau hanya makan garam demi ilmu. Hasilnya banyak orang Bugis berhasil dan duduk di parlimen, dokter, police dan cegu (Tawau, 4/7/2019).

Jumlah orang Bugis di Tawau lebih rendah daripada di daerah lainnya seperti Kalabakan di mana dari pemilih sebesar 61,014 orang tahun 2018, 21 persen adalah pemilih Bugis. Orang Bugis di seluruh Sabah lebih besar dari 108.862 berdasar pemilihanraya 2018. Hal itu disebabkan kecenderungan mereka dalam mengisi identitas, lebih memilih disebut Melayu, sama juga orang Jawa, Minang, Batak di Semenanjung, Bajau, Suluk, Bulungan, dan beberapa etnik lain. Hal itu pulalah yang membuat jumlah etnik Melayu membengkak menjadi 240.986 orang, yang terlalu besar dibanding kenyataan (Maraining, n.d.).

\section{Pelaksanaan Ibadah dan Infrastruktur Keagamaan}

Durkheim menyebutkan minimal ada tiga persyaratan agama, yaitu adanya (1) sistem kepercayaan, (2) adanya seperangkat ritus, dan (3) adanya suatu komunitas moral. 
Ketiga aspek agama itu membawa Durkheim kepada definisi agama yaitu suatu sistem kepercayaan dan kelakuan yang mempersatukan (pengikutnya) ke dalam suat u komunitas moral (Ritzer, 1992). Islam menyebut ketiganya sebagai iman, Islam, dan umat (komunitas Islam).

Pelaksanaan ibadah oleh komunitas Islam berdasarkan iman atau kepercayaan yang diyakininya menjadi indikator religiusitas mereka. Komunitas Islam Sebatik melaksanakan kewajiban agamanya, tidak berbeda dengan umat Islam di tempat lain. Indikator yang mudah kelihatan sebagai penanda adalah ketersediaan tempat ibadah, dalam hal ini masjid. Hal itu dikaitkan dengan kewajiban umat Islam untuk melaksanakan salat lima waktu secara berjamaah. Berdasarkan data di kementerian Agama Nunukan tahun 2017 di Sebatik terdapat 84 buah masjid tersebar di semua kecamatan, terbanyak di Sebatik Timur (23 buah) dan Sebatik Barat (21 buah). Sebanyak 47 persen dari 177 masjid se Kabupaten Nunukan ada di Sebatik (Profil dan Data Kementerian Agama Kabupaten Nunukan tahun 2018).

Masjid ini dimanfaatkan oleh potensi umat Islam yang jumlahnya mencapai 61.394 di pulau Sebatik. Rata-rata pengguna potensial setiap masjid sebanyak 730 orang. Islam memang hanya dicampuri oleh sekitar 590 Kristen $(0,93 \%)$ dan Katolik 1683 orang $(2,64 \%)$ dari 63.667 penduduk. Konsentrasi kaum Nasrani ada di dua kecamatan (Sebatik Barat dan Sebatik Tengah). Jumlah pemeluk Islam di Kabupaten Nunukan sendiri sebanyak 193.603 (73.14\%), Kristen 49.269 (18.61\%), Katolik 21.326 (8,06\%), Hindu 138 (0,05\%), Budha 349 (0,13\%), dan Konghucu 6 orang.

Pembangunan masjid bukan hanya menjadi indikator ketaatan beribadah, tetapi indikator ketaatan mengeluarkan zakat dan berinfak masyarakat Islam setempat. Pembangunan masjid Nurul Huda misalnya, di Desa Sei Nyamuk pada umumnya didukung oleh jamaahnya sendiri. Masjid yang menjadi ikon di Pulau Sebatik tersebut cukup megah untuk ukuran desa. Gaya arsitektur serta kaligrafi interiornya cukup menarik dan nyaman bagi jamaah. Pada tahun 2019 bulan Ramadan masjid ini mendapatkan zakat dan infak dari jamaahnya sebanyak Rp.106.000.000 (seratus enam juta rupiah). Pembangunan masjid ini didukung oleh kedermawanan jamaah yang mewakafkan tanah dan mendanai pembangunan masjid. Tradisi uang selawat dan menyerahkan zakat mal ke masjid menjadi modal utama pembangunan agama di Sebatik.

Haji merupakan rukun Islam yang mudah terdeteksi sebagai bagian dari keberagamaan Islam. Satu yang paling menonjol karena aspek demonstrative yang mudah kelihatan secara kasat mata dan usaha ekstra keras yang dilakukan untuk dapat menunaikannya. Di tengah terbatasnya kuota haji masyarakat Islam Sebatik mencatat orang-orang yang mendaftar haji lima tahun terakhir meningkat dari 393 pada tahun 2014 menjadi 436 tahun 2018. Tentu hal ini menambah panjangnya daftar tunggu dari tahun ke tahun. Mereka yang berangkat haji tahun 2014 sebanyak 32 (37,2\% dari 86 orang Jemaah haji Kabupaten Nunukan pada tahun yang sama), menjadi 59 orang tahun 2018 (52,2 \% dari 113 jumlah Jemaah haji se Kabupaten Nunukan). Panjangnya daftar tunggu membuat warga yang tidak sabar terkadang menempuh jalur pint as lewat TawiTawi di Filipina untuk berangkat haji.

Kecenderungan peningkatan pelaksanaan ibadah juga terlihat pada peningkatan peristiwa nikah di pulau ini. Tahun 2017 peristiwa nikah sebanyak 107 sement ara tahun berikutnya (2018) terjadi 252 peristiwa nikah, atau naik 57,5\%. Hal itu ditunjang dengan semakin berkembangnya sarana dan prasarana pelayanan melalui KUA. Awalnya hanya ada satu KUA untuk pelayanan umat Islam di Sebatik, yaitu KUA Kecamatan Sebatik, berdiri tahun 2001. Kecamatan ini disebut juga Sebatik induk. Meski disebut induk, kantor KUA masih menumpang di atas lahan milik Pondok Pesantren Mutiara Bangsa di Desa Padaidi Kecamatan Sebatik. Awalnya KUA ini beralamatkan di Desa Sungai Pancang Kecamatan Sebatik Utara sekarang.

Memerlukan waktu hampir satu dasa warsa untuk penambahan KUA baru (2009), yaitu KUA Sebatik Barat, yang kantornya beralamat di Desa Setabu. Tahun 2015, KUA 
Kecamatan Sebatik Timur berdiri, letaknya di Desa Sei Nyamuk. KUA ini mewilayahi tiga kecamatan, selain kecamatan Sebatik Timur sendiri juga KUA Kecamatan Sebatik Utara (ibukota di Desa Sungai Pancang) dan Sebatik Tengah di Desa Aji Kuning (Profil dan Data Kementerian Agama Kabupaten Nunukan tahun 2018). Penambahan KUA tersebut disesuaikan dengan pemekaran Kecamatan Sebatik menjadi lima kecamatan.

Pelaksanaan ibadah mahdah pada komunitas Muslim Sebatik tidak berbeda secara prinsip dengan pelaksanaan ibadah serupa di Tawau. Keduanya terikat pada tradisi Islam Aswajah. Pengamatan dua hari di Tawau memperlihatkan fenomena tersebut. Bahkan khatib di Jumat di Masjid Agung AlKautsar di Tawau berasal dari Indonesia. Bedanya sebelum azan tidak ada selawat dan dalam khotbah ada doa khusus untuk dipertuan Raja Sabah. Ketiadaan selawat atau pengajian melalui pengeras suara diduga untuk tidak mengganggu penganut agama lain. Kesamaan itu selain memperkuat hubungan umat kedua komunitas Islam, juga memperkuat moderasi beragama di kedua bangsa.

\section{Tradisi Keagamaan}

Pelaksanaan Islam tidak hanya terbatas pada ibadah wajib, tetapi juga yang mandub atau sunat, atau bahkan adat atau tradisi yang secara konseptual disebut tradisi keagamaan. Sekelompok ibu-ibu tampak sedang sibuk membereskan perlengkapan dapur pada lorong sempit yang sekaligus berfungsi jembatan penyeberangan (tidak resmi) dari Nunukan ke Sebatik. Ketika kami sedang di atas Speedboat menuju ke Sebatik saya bertanya kepada pengemudi mengenai keramaian tersebut. Ia mengatakan: "nenek saya baru diambil tujuh harinya".

Istilah "tujuh hari" merupakan salah satu rangkaian ritual berupa seperangkat upacara pemanjatan doa - biasanya tahlilan menyusul kematian seorang muslim setempat. Seorang penyuluh agama bernama Rukayah menyebutkan upacara selepas kematian seseorang berlangsung pada hari-hari ketiga, ketujuh, kesembilan, ke-40, dan hari ke-100. Bukan hanya itu. Doa untuk arwah orang meninggal dilakukan sepanjang masa, terutama pada waktu-waktu tertentu, misalnya bersamaan dengan lebaran Idul Fitri (wawancara, Juli 2019).

Pemimpin upacara tradisi seperti dipercayakan kepada imam masjid. menjadikan imam masjid di daerah ini berfungsi ganda, memimpin jamaah di masjid dan melepas hajatan jamaah di rumah-rumah. Seorang imam di Sebatik menyebutkan :

Di sini baca doanya macam-macam. Masingmasing mereka bawa (kebiasaan) dari kampungnya. Di sini ada tujuh baki, tujuh kali juga dibaca. Ada untuk kebunnya, ada untuk jualannya, ada untuk neneknya. Bahkan untuk neneknya dipisah-pisah (Haji Takka, Imam masjid Nurul Huda, wawancara, Juli 2019).

Doa untuk arwah keluarga yang sudah meninggal dunia dilakukan dalam paket yang sama dengan doa bagi keberuntungan dalam berusaha baik usaha dagang maupun usaha di bidang pertanian menunjukkan tidak ada ruang yang memisahkan orang Bugis Sebatik antara mati dan hidup, dunia dan akhirat. Persis seperti apa yang selalu dipanjatkan melalui "doa sapu jagat", rabbanaa atina fiddunya hasanah wafil akhirati hasanah waqina adzabannar". Doa untuk keselamatan dunia dan akhirat.

Doa untuk keluarga yang sudah meninggal disimbolkan dengan baki yang berisi berbagai jenis lauk pauk. Satu baki untuk satu orang at au satu arwah. Tidak boleh satu baki diperuntukkan untuk beberapa orang. Demikian pula, baki itu harus dibaca satu-persatu, tidak boleh dijamak (dirapel). Kalau ada tujuh arwah maka imam harus membaca tujuh kali. Belum lagi satu persatu dibacakan doa untuk usaha, misalnya kemaslahatan usaha dagang atau kebun. Hal seperti ini tidak berbeda dengan tradisi doa orang-orang Bugis di tempat lain, misalnya di Samarinda (Ahmad, 2017).

Tradisi syukuran kalau tamat mengaji masih dilakukan, kemudian mengundang guru. Biasanya baca barzanji. Mappanre temme, mengundang pak Imam untuk membaca. Ada juga maqjamaq untuk pak imam, tergantung kemampuan orang tua siswa mengenai besarannya (Hasniah, wawancara). 
Doa bagi kemaslahatan kehidupan di dunia dalam arti luas disimbolkan secara lebih demonstratif dengan pembacaan barzanji. Jika doa arwah dilakukan dengan seperangkat doa seperti tahlil atau sekedar membacakan doa yang biasanya dibaca untuk mayit, maka barzanji lebih banyak dibacakan untuk kegiatan syukuran dan doa kemaslahatan kehidupan duniawi. Bagian dari pengumpulan data saya lakukan dengan wawancara terhadap seorang Kepala Kantor Urusan Agama (KUA) setempat seusai salat Isya. Peneliti merasa sangat dihargai karena ia terpaksa membatalkan acara barzanji yang sedianya ia pimpin di rumah salah seorang warga yang sedang melangsung rangkaian perkawinan. Ia tidak keberatan melayani serangkaian pendalaman data karena mengaku masih ada seorang imam yang bisa menggantikannya memimpin pembacaan barzanji.

Imam Masjid Nurul Huda di Sei Nyamuk mengaku salah satu pelayanan rutin yang dilakukan adalah melayani permintaan warga untuk barzanji. Ia mengaku memiliki tim yang sudah siap memberikan pelayanan dan menggantikannya ketika ia berhalangan. Selain dikaitkan dengan perkawinan barzanji juga dibacakan saat masuk rumah baru, membuka usaha baru, atau membeli kendaraan baru. Pembacaan barzanji juga melekat pada upacara akikah atau gunting rambut seorang bayi.

Untuk kestabilan dan kemaslahatan usaha dan keluarga seorang pengusaha setempat secara rutin mengundang santrisantri tahfiz Pesantren As'adiyah di Sei Nyamuk membaca barzanji di rumahnya. Bersama imam, santri-santri ini pulalah yang melayani permintaan masyarakat untuk maksud yang sama. Santri sendiri sudah dibekali dengan kegiatan belajar membaca barzanji pada malam Jumat di Masjid Nurul Huda. Keterlibatan imam masjid dan orangorangnya, karena di Sebatik tidak dikenal istilah pegawai syara'.

Sedemikian mengakar tradisi barzanji ini sehingga tidak tergeser oleh tradisi Habsyian dari masyarakat Banjar. Orang Bugis di Samarinda, misalnya, keberadaan tradisi barzanji hanya dilakukan untuk acara akikah sementara syukuran lainnya digantikan seni Habsyian (Ahmad, 2017). Demikian mengakar tradisi barzanji sehingga oleh para pelaku penyesuaian dilakukan untuk membuat pelayanan lebih praktis dan efektif. Jika di Sulsel, tata cara membaca barzanji diurut dari satu orang ke orang berikutnya, setelah dimulai oleh pemimpin upacara, maka di Sebatik sudah ada penyesuaian. Setelah dibuka oleh Imam, para peserta (yang memiliki kemampuan membaca) kemudian membaca pasal-pasal berikutnya secara bersamaan, sesuai dengan bagian yang menjadi tanggung jawabnya. Jadi tidak ada peserta yang menganggur atau berbicara sementara yang lainnya membaca. Demikian penjelasan salah seorang penyuluh (Rusydi) mengenai perkembangan barzanji di masyarakat yang biasa dilayaninya.

Peringatan Maulid Nabi adalah salah satu hari besar Islam yang ditandai dengan pembacaan barzanji sebagai intinya. Tidak ada bedanya dengan tradisi pelaksanaan maulid di kalangan muslim tradisional di Sulawesi Selatan. Hal itu membuat peringatan maulid ini lebih ramai diikuti oleh masyarakat. Selain di masjid, warga juga ada yang melakukannya di rumah masing-masing. Mereka mengundang imam untuk membacakan barzanji dan memanjatkan doa. Ketua MUI Sebatik menyebutkan:

Di sini kalau maulid lebih ramai dari yang lain, lebih banyak telur, dan masyarakat memang yang mau datang. Saya pernah di Kampung Baru saya ceramah, ember besar ditaruh di depan saya. Saya bilang saya tidak bisa (bawa). Mereka antarkan ke rumah.

Makanan biasanya nasi ketan dan ayam atau ikan diisi ke dalam ember (sebelum ada ember biasanya bakul anyaman), yang dipersembahkan oleh warga mewakili satu keluarga dan dibawa ke masjid unt uk dimakan ramai-ramai atau dihadiahkan kepada orangorang tertentu. Besar kecilnya persembahan yang diberikan kepada seseorang tergantung pada status orang itu. Seorang penceramah atau ulama memiliki status tinggi di kalangan masyarakat seperti di Sebatik. 
Pelaksanaan tradisi seperti ini di Sebatik terkadang mengaburkan garis demarkasi antara penganut paham yang biasa disebut NU dan Muhammadiyah atau kelompok yang sering diperhadap-hadapkan dalam paham keagamaan pada umumnya. Seorang tokoh Muhammadiyah setempat, menyebutkan tidak mempermasalahkan tradisi pembacaan barzanji di kalangan masyarakat setempat. Bahkan ia sendiri sering ikut sebagai pelaku.

Saya juga pernah dikasi lemari lengkap dengan isinya. Makanya mulai saya belajar barzanji. Tidak laku kalau tidak tahu barzanji. Saya ini pimpinan cabang Muhammadiyah, saya barzanji, saya bilang apanya yang salah, ini sejarah. Bacami isinya sejarah.

\section{Tradisi Keagamaan dan Persatuan Umat}

Menarik disebutkan, fungsi ritual dalam masyarakat, oleh Durkheim disebut sebagai fungsi pemersatu di kalangan komunitas moral pendukungnya. Kasus Sebatik, keberadaan ritual bukan saja mempersatukan orang NU dan Muhammadiyah tetapi juga semua kalangan yang terlibat di dalamnya. Kalangan Muslim Sebatik mempersatukan komunitas Islam dalam budaya dominan orang Bugis sebagai nama bagi semua pendatang muslim dari Sulsel di pulau ini. Budaya dominan di sini dimaksudkan sebagai kelompok-kelompok yang sama berbagi dan memiliki materi dan sejarah yang sama, dan dalam batas tertentu budaya yang sama. Mereka memegang definisi atas dunia, peta makna yang menggambarkan situasi adanya kelompokkelompok yang memonopoli kekuasaan, juga memegang kendali pengaruh dan legitimasi terbesar dalam masyarakat (Hall, Stuart and Jefferson, 1990).

Persatuan berbasis tradisi keagamaan juga melibatkan masyarakat Islam Tidung yang juga memiliki tradisi keagamaan yang dipadukan dengan tradisi lokal. Keluwesan mereka dituangkan dalam prinsip dimanae tana biyamo, dengino kuanan sinantuk, yang berarti di mana bumi dipijak di situ langit dijunjung. Awal mula etnis ini bermukim di Pulau Sebatik bermula sekitar tahun 1912, saat mereka membuka desa Setabu atas perintah Sultan Tidung. Bahkan ada yang menyebutnya mereka sudah ada di sana sejak abad ke-17 (Sani, 2018).

Orang Bugis, sebagai pemangku budaya dominan di Sebatik, dalam hal ini tradisi keagamaan, pada prinsipnya memperlihatkan ekspresi yang sama baik di tempat asal mereka di Sulsel maupun di kalangan sesama mereka di tempat lain di luar daerah asal. Kasus detail ritual doa arwah di mana satu arwah direpresentasikan satu baki makanan, misalnya tidak hanya ditemukan di Sebatik tetapi juga di Komunitas Bugis Samarinda (Ahmad, 2017). Secara umum hal ritual seperti ini ditemukan di Sulsel. Kehidupan masyarakat Bugis adalah gambaran tentang siklus kehidupan yang penuh dengan ritual. Peristiwa senang diikuti dengan ritual syukuran dan kekhawatiran serta kesusahan dengan disertai dengan ritual tolak bala (Ahmad, 2004). Bahkan di Indonesia pun Geerts menemukan, scope Islam lebih luas dari negara lain seperti Maroko, di mana hampir segala sesuatu diwarnai dengan makna metafisis dan seluruh kehidupan sehari-hari diliputi suasana transendental. Dari aspek makna keberagamaan, di pihak Indonesia, terdapat makna kebatinan, ketenangan, kesabaran, keseimbangan, kehalusan perasaan, cita rasa tentang keindahan, dan sikap tidak menonjolkan diri, dan penghapusan individualitas secara radikal (Geertz, 1982).

Kajian tradisi keagamaan Islam menemukan bahwa tradisi siklus hidup semacam itu berlaku di umumnya komunitas Muslim di dunia. Di negara-negara muslim yang berbeda, mereka melakukan ritus-ritus peralihan yang relatif sama mulai dari kelahiran bayi, sunatan, upacara perkawinan, dan kematian dengan berbagai rangkaiannya masing-masing. Hanya saja tradisi mereka boleh jadi berbeda-beda.

Hal ini disebabkan ritus itu bukan sesuatu yang wajib seperti salat, puasa, zakat, dan haji. Tetapi sesuatu yang bersifat sunat atau bahkan adab dan adat, yang boleh berubah dari waktu ke waktu dan dari tempat ke tempat. Sebagai tanda kesenangan dan kesedihan ritus-ritus ini berfungsi mengingatkan orang Islam bahwa hanya Allah 
yang mutlak dalam segala hal (Holm, Jean with Bowker, 2014).

Bahkan ini merupakan ungkapan yang sudah ada sejak sejarah manusia itu sendiri. Seperti dikemukakan oleh Plutarch (c.46-120 $\mathrm{M}$ ), seorang sejarawan Yunani, "Anda dapat melihat negara tanpa tembok, tanpa hukum, tanpa mata uang, tanpa tulisan, akan tetapi tidak akan pernah ada orang-orang tanpa Tuhan, tanpa penyembahan, tanpa praktik keagamaan dan pengorbanan (Holm, Jean with Bowker, 2014). Hal ini menandakan betapa dalam diri manusia terkandung potensi (fitrah) untuk melakukan sesuatu yang dipersembahkan atas nama Tuhan.

Kajian Antropologi melihat tradisi keagamaan seperti itu sebagai tradisi siklus hidup (rites of the passage). Analisis mengenai upacara yang menyertai krisis kehidupan seorang individu, memiliki kontribusi yang unik. Jika dikaitkan dengan tatanan dan kandungannya, ada tiga fase aktivitas tersebut, yaitu perpisahan, peralihan atau transisi dan penyatuan (incorporation) (Gennep, 1960). Disebut upacara peralihan karena proses ritual tersebut terkait dengan perpindahan seseorang dari satu status sosial ke stat us lainnya, misalnya dari seorang anakanak menjadi dewasa atau belum kawin menjadi kawin dan menjadi bapak atau ibu (Holm, Jean with Bowker, 2014).

Di belakang ide tentang ritus peralihan terletak kenyataan bahwa seluruh kehidupan manusia ditandai proses perubahan. Mulai dari lahir, bayi, remaja, matang, berketurunan akhirnya meninggal, semuanya merupakan fakta biologis dari kehidupan. Tetapi perubahan itu bukan hanya sebuah proses biologis. Karena laki-laki dan perempuan juga merupakan makhluk sosial, dan perubahan tersebut tidak dibiarkan berlalu tanpa sebuah upacara, sebagai nilai tambah dan ditandai dengan upacara komunal yang beragam (Holm, Jean with Bowker, 2014). Lagi pula, pada tingkatan biologis dan sosial tersebut dan perubahannya dalam kehidupan manusia sering ditafsirkan melalui ide-ide keagamaan yang ditandai dengan upacara keagamaan (Holm, Jean with Bowker, 2014).

Ide tentang ritus peralihan muncul sebagai suatu upaya memaknai upacara ritual menandai berbagai perubahan sosial yang dialami oleh anggota masyarakat sepanjang perkembangan kehidupan mereka. Banyak budaya menggunakan keyakinan agama mereka untuk menjelaskan tahapan-tahapan perubahan status dan mengorganisir ritus dengan cara agama.

Selain itu ritus juga mendorong terbangunnya kembali persatuan bagi masyarakat pendukungnya. Hal ini dipahami sebagai fenomena liminal di mana ritus bertujuan menawarkan kerendahan hati dan kesakralan, homogenitas dan persahabatan. Kita disajikan, dalam upacara semacam itu, untuk keluar dari struktur sosial sekuler, dari ikatan sosial umum dari beragam ikatan struktural. Ini adalah ikatan yang diorganisasikan berdasar kasta, kelas, atau hierarki peringkat atau pertentangan segmen dalam masyarakat. Seolah-olah di sini ada dua "model" ut ama untuk keterikat an manusia dengan yang lainnya, dalam masyarakat, yang berlangsung silih berganti.

Pertama adalah masyarakat sebagai sistem posisi politik-hukum-ekonomi yang terstruktur, saling berbeda dan bersifat hierarkis, yang memisahkan manusia dalam hal "lebih" atau "kurang". Kedua, yang muncul secara sadar dalam periode liminal, adalah masyarakat sebagai komitatus yang tidak terstruktur tidak terdiferensiasi, komunitas, at au bahkan persekutuan individu yang setara yang tunduk kepada otoritas umum dari pemimpin ritual (Turner, 1969).

Terkait ritus ini Turner lebih suka istilah Latin "communitas" daripada "komunitas," untuk membedakan modalitas hubungan sosial ini dari "bidang kehidupan bersama". Perbedaan antara struktur dan komunitas bukan sekadar perbedaan antara "sekuler" dan "sakral," atau misalnya, antara politik dan agama. Tetapi ada komponen "suci" yang diperoleh oleh pemimpin upacara ritual selama upacara ritus, di mana mereka mengubah posisi.

Ini lebih merupakan masalah memberikan pengakuan pada ikatan manusia yang esensial dan generik, yang tanpanya tidak akan ada masyarakat. Liminalitas menyiratkan bahwa yang tinggi tidak mungkin tinggi kecuali yang rendah ada, dan 
dia yang tinggi harus mengalami bagaimana rasanya menjadi rendah (Turner, 1969).

Ritual adalah inti dari identitas sosial semua komunitas. Namun masing-masing masyarakat berbeda dalam pandangannya tentang apa itu ritual dan apa yang tidak. Memahami ritual mengeksplorasi bagaimana ritual dapat dipahami dalam kerangka antropologi sosial kontemporer, dan menunjukkan bahwa ritual sekarang menjadi salah satu bidang penelitian antropologi yang paling subur.

Memahami ritual menunjukkan bagaimana ritual menciptakan dan mempertahankan - atau mengubah - identitas budaya masyarakat dan hubungan sosial. Dengan memeriksa ritual-ritual ini, baik secara khusus maupun umum, para ahli memungkinkan kita untuk menemukan nilainilai pamungkas dan kontradiktif yang melekat pada setiap masyarakat sebagai satu kesatuan (Coppe, 1992).

Keragaman perwajahan Islam dengan ritualnya, dapat dipahami dalam cara pandang seperti ini. Islam merupakan air suci bersih dan jernih yang mengalir di sungai yang besar, tetapi tanpa warna. Budayalah yang memberikan warna pada Islam. Maka budaya Arab menjadikan Islam mirip Arab, dan budaya Indonesia menjadikan Islam mirip Indonesia. Selama berabad-abad, peradaban Islam menyelaraskan bentuk-bentuk ekspresi budaya asli dengan norma-norma universal dari hukum sakralnya. Itu mencapai keseimbangan antara keindahan duniawi dan kebenaran abadi yang mengipasi kesatuan ekor burang merak yang cemerlang dalam keanekaragaman, mulai dari jantung Tiongkok hingga pantai Atlantik.

Yurisprudensi Islam membantu memfasilitasi kejeniusan kreatif ini. Dalam sejarah, Islam menunjukkan dirinya ramah budaya dan, dalam hal itu, disamakan dengan sungai jernih. Perairannya (Islam) murni, manis, dan memberi kehidupan tetapi — tidak memiliki warna sendiri - mencerminkan batuan dasar (budaya asli) tempat mereka mengalir. Di Cina, Islam tampak seperti Cina; di Mali, tampak Afrika. Relevansi budaya yang berkelanjutan dengan masyarakat yang berbeda, tempat yang beragam, dan waktu yang berbeda menggarisbawahi keberhasilan panjang Islam sebagai peradaban global. Agama menjadi tidak hanya fungsional dan akrab di tingkat lokal tetapi secara dinamis melibatkan, menumbuhkan identitas Muslim pribumi yang stabil dan memungkinkan umat Islam untuk meletakkan akar yang dalam dan membuat kontribusi abadi di mana pun mereka pergi (Abd.Allah, 2012).

Ritus atau tradisi keagamaan tidak hanya diterima secara individual oleh semua anggota kelompok, tetapi juga menjadi milik kelompok dan kepercayaan itulah yang menyatukannya. Individu-individu yang menjadi bagian dari kelompok merasakan kebersamaan dengan individu lainnya dengan adanya keimanan yang diyakini bersama. Itulah yang disebut Durkheim sebagai collective conscience. Namun demikian, ada perbedaan collective conscience pada masyarakat yang memiliki solidaritas mekanik (masyarakat tradisional) dan masyarakat dengan solidaritas organik (masyarakat modern).

Masyarakat dengan tipe solidaritas mekanik memperlihatkan collective conscience yang mencakup semua masyarakat dan anggota masyarakat bersangkutan (volume); dipercaya dengan intensitas tinggi; berlaku secara rigid (ketat, kaku), dan sangat bermuatan religius. Sebaliknya pada masyarakat organik (modern) collective conscience terbatas dari segi pendukung; intensitasnya rendah, kurang rigid, dan muatannya lebih mengandung moral individualisme (Ritzer, 1992).

Perubahan masyarakat tradisional ke modern atau masyarakat desa ke kota potensial untuk juga mengubah tradisi keagamaan sebagai kesadaran kolektif masyarakat Sebatik. Anasir-anasir perubahan seperti itu kelihatan pada varian paham keagamaan yang mulai muncul yang pada gilirannya mengubah tradisi keagamaan. Perubahan juga muncul bersamaan dengan fenomena narkoba: "Saya melihat Sebatik ini berbatasan dengan negara tetangga, dan efek negatifnya adalah menjadi lalu lintas narkoba”, kata Kakankemenag Kabupaten Nunukan. Kerawanan Sebatik terhadap transaksi narkoba dan lalu lintas terorisme 
tetap menjadi perhatian dan kewaspadaan lokal. Hal itu ditandai dengan penjagaan wilayah yang relatif ketat baik di tapal batas, maupun sepanjang jalan masuk dan keluar Sebatik.

Salah satu terapi untuk mengatasi fenomena tersebut ditawarkan oleh Kakankemenag Nunukan dengan rencana besar pembentukan Sebatik sebagai Pulau Santri. "Masalah besar saya di sini adalah bahwa kami ingin mencetuskan Sebatik sebagai Pulau Santri. Pencanangannya tanggal 22 Oktober 2019 bertepatan hari Santri, oleh Pemerintah Daerah". (wawancara, 17/6/2019).

\section{PENUTUP}

Masalah-masalah yang muncul di sekitar posisi Sebatik sebagai daerah tapal batas (borderlands) adalah isu-isu tentang penyeberangan ilegal, perdagangan ilegal, administrasi kependudukan, selain isu tentang jalur narkoba dan lalu lintas terorisme. Hal it u membawa dampak bagi transaksi ekonomi yang melibatkan masyarakat dari dua negara, relasi sosial antara mereka dan jaminan keamanan secara umum. Selain itu, problem administrasi kependudukan berdampak bagi keharusan memperoleh pelayanan di bidang pendidikan, kesehatan, dan administrasi pernikahan bagi warga.

Problem-problem tersebut, meski merupakan agenda penting yang harus menjadi perhatian pemerintah, keberadaan warga dari kedua negara diuntungkan oleh keadaannya sebagai integrated borderlands di mana hubungan-hubungan mereka didasarkan pada lebih banyak atas dasar kesamaan tradisi agama, budaya, hubungan sosial dan kekerabatan.

Selain latar belakang tersebut, kesatuan dan keharmonisan hubungan sosial atas dasar kesamaan tradisi keagamaan lebih kuat menopang persatuan dan kerukunan ketimbang kesamaan berbasis agama semata. Karena itu umat beragama, tidak cukup melakukan ajaran agama secara formal tetapi dibumikan sehingga menjadi bagian tak terpisahkan dari tradisi beragama masyarakat setempat. Tradisi keagamaan menjadi inti budaya yang dapat menembus batas-batas organisasi, tempat dan wilayah.

\section{UCAPAN TERIMA KASIH}

Saya ucapkan terima kasih kepada semua pihak yang telah memungkinkan penelitian ini terlaksana, terutama Kepala Balai Penelitian Agama Makassar yang menugaskan penulis melakukan penelitian di daerah Sebatik. Terima kasih juga saya sampaikan kepada semua jajaran Kementerian Agama Kabupaten Nunukan hingga ke para Kepala Kantor Urusan Agama di Pulau Sebatik. Tidak lupa pula saya ucapkan terima kasih kepada para ulama, pimpinan pondok pesantren dan Madrasah serta guru-guru dan mereka yang tidak dapat saya sebutkan namanya satu persatu.

\section{DAFTAR PUSTAKA}

Abd.Allah, U. F. 2012. Islam and the Cultural Imperative. Islam and Civilisational Renewel, 3(4), 1-14.

Ahmad, A. K. 2004. Ulama Bugis. Makassar: Indobis.

Ahmad, A. K. 2017. Pendidikan Keagamaan Migran Bugis di Samarinda. Makassar.

Bangun, B. H. 2017. Konsepsi dan Pengelolaan Wilayah Perbatasan Negara: PerspeKtif Hukum Internasional. Tanjungpura Law Journal, 1(1), 52-63.

Batubara, H. 2016. Jadikan Sebatik Ikon Kota Perbatasan.

Diener, A. C. and, \& Hagen, J. (Eds.). 2010. Borderlines and Borderlands: Political Oddities at the Edge of the Nation-State. Lanham - Boulder - New York • Toronto - Plymouth, UK: Rowman \& Littlefield Publishers, Inc.

Geertz, C. 1982. Islam Yang Saya Amati, Perkembangan di Maroko dan Indonesia. Jakarta: Yayasan Ilmu Sosial Indonesia.

Gennep, A. van. 1960. The Rites of Passage. USA: The University of Chicago Press. 
Ghafur, M. F. 2016. Ketahanan Sosial di Perbatasan: Studi Kasus Pulau Sebatik. Masyarakat Indonesia, Vol. 42 No.2, Desember 2016, 42(2), 233-247.

Hall, Stuart and Jefferson, T. (Ed.). 1990. Resistance through Rituals: Youth Subcultures in Post-War Britain (1st ed.). UK: Routledge.

Holm, Jean with Bowker, J. (Ed.). 2014. Rites of Passage. London and New York: Pinter Publisher.

Khan, S. W. 2015. Muslim, Trader, Nomad, Spy: China's Cold War and the People of the Tibetan Borderlands (The New Cold War History). USA: The University of North Carolina Press.

Konrad, V. 2013. Imagining and Imaging Borders: Understanding Borderlandas for Global Sustainability. The International Archives of the Photogrammetry, Remote Sensing and Spatial Information Sciences, Volume $X L-4 / W 3,2013, X L, 1-5$.

Maraining, A. et. a. (n.d.). Bugis di Sabah dan Pru-14: Kajian Kes Parlimen Kalabakan Bugis in Sabah and GE-14: Case Study of Kalabakan Parliament.
Peraturan Pemerintah Republik Indonesia Nomor 55 Tahun 2007 Tentang Pendidikan Agama dan Pendidikan Keagamaan. (n.d.).

Ritzer, G. 1992. Sociological Theory (I. McGraw-Hill., ed.). New York.

Saleh, M. H. 2015. Dinamika Masyarakat Perbatasan (Eksistensi Perantau Bugis di Pulau Sebatik Kalimantan Utara: Perspektif Cultural Studies). Jurnal Borneo, 11(1), 31-48.

Sani, M. Y. 2018. Orang Tidung dI Pulau Sebatik, Identitas Etnik, Budaya dan Kehidupan Keagamaan. Jurnal "AlQalam," 24(1).

Schofield, C. H. (Ed.). 1994. Global Bounderies, World Boundaries Volume 1. London and New York: Routledge.

Siburian, R. 2012. Pulau Sebatik: Kawasan Perbatasan Indonesia Beraroma Malaysia. Jurnal Masyarakat \& Budaya, 14(1), 53-76.

Turner, V. (Ed.). 1969. The Ritual Process: Structure and Anti-Structure,. New York: Cornell University Press. 
